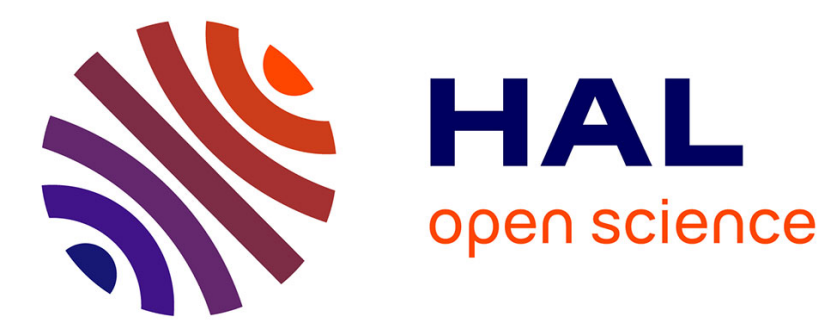

\title{
Deforestation and Seigniorage in Developing Countries: A Tradeoff?
}

Jean-Louis Combes, Pascale Combes Motel, Alexandru Minea, Patrick Villieu

\section{To cite this version:}

Jean-Louis Combes, Pascale Combes Motel, Alexandru Minea, Patrick Villieu. Deforestation and Seigniorage in Developing Countries: A Tradeoff?. 2014. halshs-00939273v1

\section{HAL Id: halshs-00939273 \\ https://shs.hal.science/halshs-00939273v1}

Preprint submitted on 30 Jan 2014 (v1), last revised 8 Jun 2015 (v2)

HAL is a multi-disciplinary open access archive for the deposit and dissemination of scientific research documents, whether they are published or not. The documents may come from teaching and research institutions in France or abroad, or from public or private research centers.
L'archive ouverte pluridisciplinaire HAL, est destinée au dépôt et à la diffusion de documents scientifiques de niveau recherche, publiés ou non, émanant des établissements d'enseignement et de recherche français ou étrangers, des laboratoires publics ou privés. 


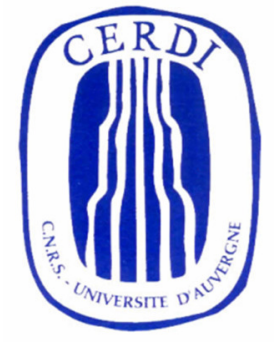

CENTRE D'ETUDES ET DE RECHERCHES SUR LE DEVELOPPEMENT INTERNATIONAL

\section{SERIE ETUDES ET DOCUMENTS DU CERDI}

\section{Deforestation and Seigniorage in Developing Countries: A Tradeoff?}

J.-L. Combes, P. Combes-Motel, A. Minea and P. Villieu

Etudes et Documents $\mathrm{n}^{\circ} 22$

December, 2013 


\section{The authors}

\section{Jean-Louis COMBES}

Clermont Université, Université d'Auvergne, CNRS, UMR 6587, CERDI, F-63009 Clermont Fd Email: j-I.combes@udamail.fr

\section{Pascal COMBES-MOTEL}

Clermont Université, Université d'Auvergne, CNRS, UMR 6587, CERDI, F-63009 Clermont Fd email: Pascale.motel_combes@udamail.fr

Corresponding author

\section{Alexandru MINEA}

Clermont Université, Université d'Auvergne, CNRS, UMR 6587, CERDI, F-63009 Clermont Fd Email : Alexandru.Minea@udamail.fr

\section{Patrick VILLIEU}

Université d'Orléans, LEO, 45067 Orléans cedex2

Email : patrick.villieu@univ-orleans.fr

La série des Etudes et Documents du CERDI est consultable sur le site :

http://www.cerdi.org/ed

Directeur de la publication : Patrick Plane

Directeur de la rédaction : Catherine Araujo Bonjean

Responsable d'édition : Annie Cohade

ISSN : 2114 - 7957

\section{Avertissement :}

Les commentaires et analyses développés n'engagent que leurs auteurs qui restent seuls responsables des erreurs et insuffisances. 


\begin{abstract}
Most of countries covered by natural forests are developing countries, with limited ability to levy taxes and restrained access to international credit markets; consequently, they are amenable to draw heavily on two sources of government financing, namely seigniorage and deforestation revenues. First, we develop a theoretical model emphasizing a substitution effect between seigniorage and deforestation revenues. Second, a panel-data econometric analysis over the 1990-2010 period confirms our findings. Consequently, a tighter monetary policy hastens deforestation. Third, we extend the theoretical model and show that international transfers dedicated to forest protection can upturn the positive link between tighter monetary policies and deforestation, and then discuss the relevance of this finding with respect to recent institutional arrangements.
\end{abstract}

Keywords: deforestation, seigniorage, inflation, developing countries, panel data analysis

JEL codes: O13, Q23, E42, E52

A previous version of this manuscript was presented at ISDRC (New York) conference and seminars in ERUDITE (Paris), BETA (Strasbourg), CERDI (Clermont) and LEO (Orléans). The authors are indebted to J.-L. Arcand, T. Azomahou, I. Bateman, R. Dos Santos Ferreira, S. Guillaumont, P. Guillaumont, L. Hotte, J. Hudson, E. Reis, K. Schubert and T. Sterner. Usual disclaimers apply. P. Combes Motel acknowledges financial support from the French Ministry of Research grant ACl "Macroeconomic Policies and Deforestation in Developing Countries". 


\section{Introduction}

During her speech at the Center for Global Development, IMF Managing Director Christine Lagarde warned on a triple crisis - Economic, Environment, Social - and announced IMF research support on the use of fiscal tools in climate policies (e.g. De Mooij et al. 2012). This warning signals a clear recognition of a close linkage between macro and environmental outcomes within an institution which traditionally targeted economic performance in a narrow sense. Moreover, many observers outlined the link between lower deforestation rates and the financial crisis, which dried up credit flows towards activities fueling deforestation: for example, Nepstad et al. (2009) did not exclude that the 2008-2009 financial crisis had something to do with an impressive decrease in deforestation rates in the Amazonian region. This proposition makes reminiscent earlier debates between those arguing that economic growth is detrimental to the environment (e.g. Meadows et al. 2005) and those promoting economic growth as a mean to alleviate the pressure on the environment (e.g. Beckerman 1992). The objective of this paper is precisely to build on this link between macroeconomics and the environment; namely, it focuses on the channel through which macroeconomics may alter environmental quality.

Several authors addressed the relationship between macroeconomic performances and environmental issues. Significant contributions include the pioneer work of Grossman \& Krueger (1995), showing the existence of an "environmental Kuznets curve" (EKC), and the study of the relation binding economic growth and the environment (see, for example, Bovenberg \& Smulders 1995 or more recently Fullerton \& Kim 2008). As regards deforestation, several authors paid attention to the role of macroeconomic factors in the process of deforestation, in the wake of the economic reforms implemented under structural adjustment programs in the 1990s. For instance, Angelsen \& Kaimowitz (1999) found that adjustment programs may increase the pressure on forests, a view supported by other studies focusing on debt and deforestation (Culas 2006). Trade liberalization affects deforestation in a more ambiguous way, through movements in prices of agricultural outputs and inputs as well as timber prices (Robalino \& Herrera 2010), while relative prices, measured by real exchange rates, were shown to determine deforestation dynamics (Arcand et al. 2008).

In this paper we explore the link between macroeconomic performances and environmental issues by explicitly modeling a tradeoff between economic and environmental performances. 
More precisely, in the wider environment-development dilemma (see e.g. Combes Motel et al. 2013) context, we analyze a possible tradeoff between inflation-fighting policies and deforestation, through the government budget constraint. Our starting point is that the majority of countries covered by natural forests are developing countries, having limited ability to levy taxes and restrained access to international credit markets. This is consistent with recent studies on tax revenues in developing compared to developed ones: in highincome countries over the 1994-2009 period, tax revenues represent a larger fraction of GDP and have increased faster than in middle-income and poor countries (Le et al. 2012). ${ }^{1}$ This fact is explained either by differences in preferences towards public versus private goods or as deficient tax collection systems (Gordon \& Li 2009). Consequently, developing countries can be incited to draw on two sources of government financing, namely resource harvesting and seigniorage revenues.

We pay special attention to "deforestation revenues" accruing to governments, namely revenues generated by timber harvesting as well as revenues from land-use change activities, i.e. government revenues resulting from encroachments of agriculture and cities on forested areas. Indeed, the outcome of deforestation can represent an important source of government revenues; this is all the more true in developing economies, where forest is cleared for agriculture, forestry or commercial purposes, and there can be a pressure for developing its exploitation or for converting it for obtaining "deforestation revenues". They are meant to cover revenues generated by timber harvesting as well as by land-use changes, i.e. from forested areas converted to agricultural areas (crop revenues and livestock), and to a lesser extent revenues from urban areas. In other words, "deforestation revenues" are closely linked to drivers of deforestation as described by several authors, among which Chomitz (2007) or Geist \& Lambin (2001), who have put emphasis on their diversity. It is worth noticing that the last Forest Resource Assessment issued in 2010 by the FAO provides estimates of "forest revenues" defined as "all government revenue[s] collected from the domestic production and trade of forest products and services" (FAO 2010). They amount to 14.6 billion USD in 2005 and widely underestimate all "deforestation revenues", i.e. revenues generated by deforestation activities. We argue here that the most appropriate way to seize "deforestation revenues" is to consider rates of deforestation.

\footnotetext{
${ }^{1}$ Tax revenues as a fraction of GDP equal $21.2 \%, 18.8 \%$ and $11.3 \%$ in respectively high-income, middle-income and poor countries in 1994, while in 2009 figures are 29.3, 19.3 and 13.6 respectively (Le et al. 2012).
} 
Deforestation activities have negative effects on the environment. For instance, forests are the second biggest stock of carbon after Oceans, ${ }^{2}$ therefore contributing to mitigating climate change. They provide a habitat for a wide range of known and unknown species over the planet, which can be potentially driven by human encroachments to an extinction (Laurance et al. 2012). Moreover, land use changes, which are mainly the result of deforestation, are responsible for about 25\% anthropogenic CO2 emissions (Denman et al. 2007). Houghton (2005) estimates that the magnitude of carbon released by tropical deforestation is about 15 to $35 \%$ of annual fossil fuel emissions during the 1990s, and Van der Werf et al. (2009) conclude that forest losses are substantial contributors to GHG emissions into the atmosphere. At last, forests contribute to the water cycle: the Amazon basin accounts for one fifth of total freshwater drained into oceans. Data show that deforestation occurs at a yearly pace of about than 7 million hectares per year between 1990 and 2010 (Table 1), Africa being mostly affected by deforestation (Table 2).

Table 1 - Forested areas (in thousands hectares, source FAOSTAT)

\begin{tabular}{|l|r|r|r|r|r|}
\hline Regions / Years & 1990 & 1995 & 2000 & 2005 & 2010 \\
\hline Latin America & $1,048,363$ & $1,023,924$ & 999,486 & 975,308 & 955,584 \\
\hline Africa & 749,238 & 728,901 & 708,564 & 691,468 & 674,408 \\
\hline Asia & 560,209 & 573,137 & 570,164 & 584,049 & 592,512 \\
\hline Northern America & 606,474 & 608,404 & 610,333 & 612,246 & 614,160 \\
\hline Europe & $1,005,372$ & 993,855 & 998,239 & $1,001,150$ & $1,005,001$ \\
\hline Oceania & 198,744 & 198,563 & 198,381 & 196,745 & 191,384 \\
\hline World & $4,168,400$ & $4,126,784$ & $4,085,169$ & $4,060,965$ & $4,033,049$ \\
\hline
\end{tabular}

Table 2 - Deforestation rates in developing countries (1990-2010 average annual rates in \%)

\begin{tabular}{|c|c|c|c|c|c|c|c|c|c|c|}
\hline Regions/ Periods & $\begin{array}{l}1990- \\
2010\end{array}$ & $\mathrm{Nb}$ & $\begin{array}{l}1990- \\
1995\end{array}$ & $\mathrm{Nb}$ & $\begin{array}{l}1996- \\
1999\end{array}$ & $\mathrm{Nb}$ & $\begin{array}{l}2000- \\
2004\end{array}$ & $\mathrm{Nb}$ & $\begin{array}{l}2005- \\
2010\end{array}$ & $\mathrm{Nb}$ \\
\hline $\begin{array}{l}\text { Latin America } \\
\text { and the Caribbean }\end{array}$ & $\begin{array}{l}0.18 \\
(0.04)\end{array}$ & 20 & $\begin{array}{l}0.16 \\
(0.11)\end{array}$ & 20 & $\begin{array}{l}0.20 \\
(0.10)\end{array}$ & 20 & $\begin{array}{l}0.19 \\
(0.07)\end{array}$ & 20 & $\begin{array}{l}0.18 \\
(0.09)\end{array}$ & 20 \\
\hline $\begin{array}{l}\text { Sub-Saharan } \\
\text { Africa }\end{array}$ & $\begin{array}{l}0.30 \\
(0.03)\end{array}$ & 40 & $\begin{array}{l}0.29 \\
(0.06)\end{array}$ & 38 & $\begin{array}{l}0.32 \\
(0.07)\end{array}$ & 40 & $\begin{array}{l}0.28 \\
(0.07)\end{array}$ & 40 & $\begin{array}{l}0.30 \\
(0.07)\end{array}$ & 40 \\
\hline South Asia & $\begin{array}{l}0.17 \\
(0.06)\end{array}$ & 6 & $\begin{array}{l}0.19 \\
(0.15)\end{array}$ & 6 & $\begin{array}{l}0.22 \\
(0.16)\end{array}$ & 6 & $\begin{array}{l}0.16 \\
(0.16)\end{array}$ & 6 & $\begin{array}{l}0.12 \\
(0.15)\end{array}$ & 6 \\
\hline $\begin{array}{l}\text { East Asia and } \\
\text { Pacific }\end{array}$ & $\begin{array}{l}0.10 \\
(0.06)\end{array}$ & 11 & $\begin{array}{l}0.08 \\
(0.12)\end{array}$ & 11 & $\begin{array}{l}0.10 \\
(0.11)\end{array}$ & 11 & $\begin{array}{l}0.09 \\
(0.13)\end{array}$ & 11 & $\begin{array}{l}0.13 \\
(0.10)\end{array}$ & 11 \\
\hline $\begin{array}{l}\text { All developing } \\
\text { countries }\end{array}$ & $\begin{array}{l}0.23 \\
(0.03)\end{array}$ & 77 & $\begin{array}{l}0.20 \\
(0.05)\end{array}$ & 75 & $\begin{array}{l}0.23 \\
(0.05)\end{array}$ & 77 & $\begin{array}{l}0.24 \\
(0.05)\end{array}$ & 77 & $\begin{array}{l}0.24 \\
(0.06)\end{array}$ & 77 \\
\hline
\end{tabular}

Note: standard deviations in brackets. Nb: number of countries. Source: FAO and authors' calculations. List of countries in Appendix A3.

\footnotetext{
${ }^{2}$ According to IPCC, it is however likely the case that CO2 uptake from the atmosphere by oceans will decrease (IPCC 2007, paragr.7.3.4.2), thus reinforcing the role of forests as carbon sink.
} 
Data over the 1990-2010 period (Table 3) show that seigniorage revenues account for $1 \%$ to $10 \%$ and $20 \%$ of GDP in sub-Saharan African countries. Figures are indeed particularly high in the latter countries and confirm that over the 19901995 period, African countries had higher seigniorage revenues which thereafter decreased up to 2010. The dispersion of seigniorage revenues is also very high in this region. In other developing regions, seigniorage revenues represent a non-negligible fraction of GDP, which decreased over the period. It seems therefore that seigniorage revenues were impacted by disinflation policies as promoted by the IMF.

Table 3 - Seigniorage revenues (\% of GDP, 1990-2010)

\begin{tabular}{|l|l|l|l|l|l|l|l|l|l|l|}
\hline & $\begin{array}{l}1990- \\
2010\end{array}$ & $\mathrm{Nb}$ & $\begin{array}{l}1990- \\
1995\end{array}$ & $\mathrm{Nb}$ & $\begin{array}{l}1996- \\
1999\end{array}$ & $\mathrm{Nb}$ & $\begin{array}{l}2000- \\
2004\end{array}$ & $\mathrm{Nb}$ & $\begin{array}{l}2005- \\
2010\end{array}$ & $\mathrm{Nb}$ \\
\hline $\begin{array}{l}\text { Latin America and } \\
\text { the Caribbean }\end{array}$ & $\begin{array}{l}0.86 \\
(0.13)\end{array}$ & 15 & $\begin{array}{l}1.45 \\
(0.39)\end{array}$ & 14 & $\begin{array}{l}0.67 \\
(0.22)\end{array}$ & 14 & $\begin{array}{l}0.52 \\
(0.07)\end{array}$ & 15 & $\begin{array}{l}0.82 \\
(0.21)\end{array}$ & 15 \\
\hline Sub-Saharan Africa & $\begin{array}{l}21.66 \\
(10.90)\end{array}$ & 37 & $\begin{array}{l}34.68 \\
(33.54)\end{array}$ & 35 & $\begin{array}{l}19.42 \\
(18.11)\end{array}$ & 35 & $\begin{array}{l}15.51 \\
(15.78)\end{array}$ & 35 & $\begin{array}{l}17.03 \\
(16.26)\end{array}$ & 35 \\
\hline South Asia & $\begin{array}{l}1.15 \\
(0.09)\end{array}$ & 5 & $\begin{array}{l}1.15 \\
(0.22)\end{array}$ & 5 & $\begin{array}{l}1.03 \\
(0.15)\end{array}$ & 5 & $\begin{array}{l}0.98 \\
(0.14)\end{array}$ & 5 & $\begin{array}{l}1.42 \\
(0.15)\end{array}$ & 5 \\
\hline $\begin{array}{l}\text { East Asia and } \\
\text { Pacific }\end{array}$ & $\begin{array}{l}1.17 \\
(0.19)\end{array}$ & 10 & $\begin{array}{l}1.65 \\
(0.50)\end{array}$ & 9 & $\begin{array}{l}0.96 \\
(0.32)\end{array}$ & 10 & $\begin{array}{l}1.10 \\
(0.39)\end{array}$ & 10 & $\begin{array}{l}1.02 \\
(0.29)\end{array}$ & 9 \\
\hline $\begin{array}{l}\text { All developing } \\
\text { countries }\end{array}$ & $\begin{array}{l}11.04 \\
(5.34)\end{array}$ & 67 & $\begin{array}{l}17.29 \\
(16.08)\end{array}$ & 63 & $\begin{array}{l}9.59 \\
(8.57)\end{array}$ & 64 & $\begin{array}{l}7.61 \\
(6.90)\end{array}$ & 65 & $\begin{array}{l}8.64 \\
(7.79)\end{array}$ & 64 \\
\hline
\end{tabular}

Note: seigniorage revenues are calculated as average annual variations in reserves between $t$ and (t-1) over GDP at $t$. Standard deviations in brackets; Nb: number of countries. Source: IFS, World Bank Indicators and authors' calculations. List of countries in Appendix A3.

The rest of the paper is organized as follows. In section 2, we develop a simple theoretical model that establishes the existence of an optimal (welfare-maximizing) tradeoff between seigniorage and deforestation revenues. In particular, the higher the pressure on lowering inflation (for example, through inflation targeting), the higher the deforestation. Section 3 is devoted to the empirical assessment of this proposition. An econometric analysis performed on a panel of developing countries support the theoretical conclusions. In light of the results, tight monetary policies designed for reducing inflation might hasten deforestation. To tackle this problem, we extend the theoretical model in section 4, by considering an international transfer for compensating deforestation reduction. We show that a welfare-maximizing contract based on environmental rewards could circumvent the problem of substitutability between inflation-fighting and environmental policies, and provide a "win-win" strategy. Such a contract might meet several recent initiatives, as for example the advances of the $16^{\text {th }}$ CoP held in Cancún, towards compensations of developing countries which protect their forests, as emphasized in section 5. 


\section{A model of substitution between seigniorage and deforestation revenues}

\section{1/ The theoretical setup}

Suppose that citizens of some country have the following social welfare function, which depends on inflation $(\pi)$, public spending $(g)$ and deforestation $(R)$

$$
V(\pi, g, R)=-\frac{1}{2}\left\{(\pi-\bar{\pi})^{2}+\lambda(g-\bar{g})^{2}+\mu(R-\bar{R})^{2}\right\}
$$

According to (1), citizens value three objectives. First, inflation deviations (from the target $\bar{\pi})$ may affect welfare, as usual in the literature on monetary policy. Effectively, high inflation can disrupt the intertemporal choices of households, but very low (or negative) rates of inflation are probably associated with situations of macroeconomic deflation, which are also harmful to welfare, hence the positive inflation target $\bar{\pi}$. Compared to developed countries, such social costs of inflation deviations are probably higher in developing countries, with high inflation and limited indexation mechanisms. Second, public expenditures can be allocated to economic and social goals (for example expenditures devoted to public infrastructures or to fight poverty). Following Alesina \& Tabellini (1987), we assume a target value for public expenditures $(\bar{g})$, which can be treated as an indicator of "development" goals of society. The target $\bar{g}$ could eventually emerge from an endogenous growth model similar to Barro (1990), in which productive public spending exerts a positive influence on long-run economic growth, but must be financed by taxes, which crowd out private investment. In such a case, the tradeoff between the productive effect of public expenditures and the crowing out effect of taxes results in an optimal target for $g$.

Third, to account for the evidence in the introduction, emphasizing the growing interest of “sustainable development" in both peoples' conscience and politics' concerns, we consider an environmental objective in the welfare function. Namely, in countries endowed with natural resources, citizens may be interested in preserving the resource, by defending a targeted rate of deforestation $(\bar{R})$. Suppose for example that long-run economic growth $(\gamma)$ positively depends on deforestation $(R)$ and (with the above-described non-linear effect) on public expenditures: $\gamma=f\left(\begin{array}{c}R, g \\ ++\end{array}\right)$. Suppose moreover that environmental quality $(N)$ negatively 
depends on deforestation: $N=h(\underset{-}{R})$. Then, social welfare depends on inflation, economic growth and environmental quality: $V=\Omega(\gamma, N, \pi)$. The social welfare function (1) can be seen as a reduced form of the general function $\Omega($.$) , in which \bar{g}$ summarizes the tradeoff between the growth effect and the crowding-out effect of public expenditures, and $\bar{R}$ summarizes the tradeoff between long-run economic growth and environmental quality. ${ }^{3}$ Thus, the targeted rate of deforestation $(\bar{R})$ corresponds to an optimal rate that solves the intertemporal tradeoff between macroeconomic and environmental concerns, from the point of view of domestic citizens. However, as we will see, $\bar{R}$ may be suboptimal from a global point of view, if deforestation gives rise to international spillovers. Finally, strictly positive parameters $\lambda$ and $\mu$ capture the relative weights of public spending and environmental objectives in the citizens' welfare function.

A single Monetary and Fiscal Authority (the "Government") finances public spending by the means of deforestation revenues and from seigniorage (the presence of a single authority may be compatible with the fact that seigniorage revenues are available at no transfer cost, for example). We assume Laffer-efficiency of the seigniorage collection, namely seigniorage is positively related to inflation (we stick to the increasing part of the seigniorage Laffer curve). Moreover, we assume that deforestation revenues are positively related to deforestation. The government budget constraint is

$$
g=R+\alpha \pi+\beta\left(\pi-\pi^{e}\right), \alpha>0 ; \beta \geq 0,
$$

where $\pi^{e}=E \pi$ is the (rational) expected inflation rate.

The last term of (2) accounts for the possibility of time inconsistency of monetary policy; such time inconsistency justifies the inflation target we introduce below. We assume that time inconsistency of monetary policy comes from the government budget constraint; ${ }^{4}$ if, for example, government can benefit from surprises on seigniorage, because the demand for money depends on the nominal interest rate, thus on expected inflation (Cagan 1956).

\footnotetext{
${ }^{3}$ The target $\bar{\pi}$ summarizes the well-know tradeoff between the social costs and benefits of inflation, but could also arise from a non-linear effect of inflation on growth: $\gamma=f\left(\begin{array}{c}R, g, \pi \\ +++_{-}-\end{array}\right)$, without any change in (1).

${ }^{4}$ Another source for time-inconsistency may arise from inflation surprises from the expectational Phillips curve; but such real wage surprises are unlikely to have a great influence on economy in developing countries, with weak contractual relations on the labor market.
} 
Effectively, unexpected inflation reduces the nominal interest rate and induces households to demand more real balances, which allows the government to issue more money in real terms. ${ }^{5}$ Calvo (1978) and Barro \& Gordon (1983), among others, have shown that this "inflationary finance" can provide a valuable way of government finance if alternative methods of raising revenue (such as an income tax) entail distortions. ${ }^{6}$ The term $\beta\left(\pi-\pi^{e}\right)$ reflects the incentive for the government to raise financial resources by deceiving money holders; finally, all results are independent of the value of $\beta \geq 0$ (including dollarized economies, i.e. $\beta=0$ ). ${ }^{7}$

\section{2/ The environmental-disinflation tradeoff}

As a benchmark, let us present the commitment solution of the game, in which the government maximizes the welfare $V(\pi, g, R)$ and internalizes the effect of the inflation rate on expectations, so that public expenditures are simply: $g=R+\alpha \pi$. First-order conditions on inflation and deforestation revenues $(\partial V(.) / \partial \pi=0$ and $\partial V(.) / \partial R=0)$ give rise to: $\pi-\bar{\pi}+\alpha \lambda(g-\bar{g})=0$ and $\lambda(g-\bar{g})+\mu(R-\bar{R})=0$, respectively. Using these two relations,

\footnotetext{
${ }^{5}$ Suppose that the Government budget constraint is the following: $G_{t}=D_{t}+\left(M_{t+1}-M_{t}\right) / P_{t}$ where $G_{t}$ and $D_{t}$ are government spending (adjusted from taxes on personal income) and deforestation revenues, respectively; and $\left(M_{t+1}-M_{t}\right) / P_{t}$ represents the real value of seigniorage. Suppose that the demand for real balances is defined by the usual relation: $M_{t} / P_{t}=Y_{t} \exp (-\varphi i)$, where $i=r+\pi^{e}$ is the nominal interest rate ( $r$ is the real interest rate and $\varphi$ a positive parameter); we can write: $\left(G_{t}-D_{t}\right) / Y_{t}=\left(M_{t+1}-M_{t}\right) / P_{t} Y_{t}=\left(\left(M_{t+1}-M_{t}\right) / M_{t}\right) \exp (-\varphi i)$. We approximate the rate of seigniorage by the rate of inflation $\left(M_{t+1}-M_{t}\right) / M_{t} \approx \pi_{t}$, thus: $1+\left(G_{t}-D_{t}\right) / Y_{t}=$ $(\exp (\varphi i)+\pi) \exp (-\varphi i)$. Let us define $g \equiv G_{t} / Y_{t}$ and $R \equiv D_{t} / Y_{t}$. For "small" nominal interest and inflation rates (formally, $\pi \rightarrow 0$ and $i \rightarrow 0$ ), we can use the following logarithmic approximation of the government budget constraint: $\ln (1+g-R) \approx-\varphi i+\ln (1+\pi) \Rightarrow g-R \approx \pi-\varphi i$. Thus: $g \approx R+(1-\varphi) \pi+\varphi\left(\pi-\pi^{e}\right)-\varphi r$. We find relation (2) in main text by setting $\alpha \equiv 1-\varphi$ and $\beta \equiv \varphi$ (we should have $\beta=1-\alpha$, but we prefer the more general form in equation (2)), and by neglecting the constant term $\varphi r$.

${ }^{6}$ The temptation to generate inflation surprises relates to governmental liabilities that are fixed in nominal terms, rather than to money per se. Thus, the same argument may apply to nominally-denominated interest-bearing public debt: unexpected inflation is a source of government revenue if it reduces the real value of the debt burden (because the nominal interest rate on debt depends on expected inflation). However, this source of revenue is limited in developing and emerging countries, because public debt is most often denominated in foreign currency, thus immunized to domestic inflation surprises. Similarly, seigniorage revenues from unexpected inflation are unlikely to arise in dollarized economies. In those economies, we would have $\beta=0$, without any change in the main results.

${ }^{7}$ In the government budget constraint (2), we disregard other taxes and public debt financing, not because they are unimportant, but because we consider that they are more difficult to vary than taxes on money or deforestation revenues, which are the most convenient way (in terms of political cost) to finance public spending. However, notice that our results are generalized to other sources of government finance in Appendix Al.
} 
inflation and deforestation revenues are jointly determined: $\pi=\frac{\bar{\pi}+\alpha \lambda(\bar{g}-R)}{1+\alpha^{2} \lambda}$ and $R=\frac{\mu \bar{R}-\lambda(\alpha \pi-\bar{g})}{\mu+\lambda}$. Notice in the latter relations that $\pi$ and $R$ are substitute ways of government finance. The commitment solution is then easily obtained (we suppose that $\bar{g}>\bar{R}+\alpha \bar{\pi}$, for positive solutions with time inconsistency)

$$
\begin{aligned}
& \pi^{c}=\bar{\pi}+\alpha \lambda \mu \eta^{c}(\bar{g}-\bar{R}-\alpha \bar{\pi}), \\
& R^{c}=\bar{R}+\lambda \eta^{c}(\bar{g}-\bar{R}-\alpha \bar{\pi})
\end{aligned}
$$

where $\eta^{c} \equiv\left[\lambda+\mu\left(1+\alpha^{2} \lambda\right)\right]^{-1}$.

In light of the so-called "Tinbergen rule", the problem may be considered as a Mundelllike "triangle of impossibility", between economic development (i.e. the goal linked to the public spending target), environmental goals and inflation, meaning that the first-best ( $\pi^{F B}=\bar{\pi}, R^{F B}=\bar{R}$ and $g^{F B}=\bar{g}$ ) cannot be achieved.

Figure 1 - An environmental "triangle of impossibility"

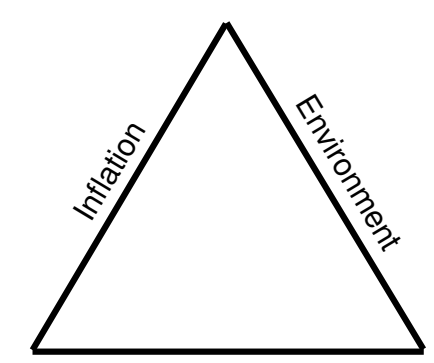

Economic Development

Effectively, if deforestation was a free variable $(\mu=0)$, government could achieve the two other goals $\left(\pi^{c}=\bar{\pi}\right.$ and $\left.g^{c}=\bar{g}\right)$ by setting $R^{c}=\bar{g}-\alpha \bar{\pi} \neq \bar{R}$. Similarly, if economic development was disregarded $(\lambda=0)$, inflation and environmental targets could be reached ( $\pi^{c}=\bar{\pi}$ and $R^{c}=\bar{R}$ ), with $g^{c}=\alpha \bar{\pi}+\bar{R} \neq \bar{g}$. Finally, if inflation was the free variable $(\lambda=\mu=+\infty)$, the government could achieve development and environmental goals $\left(g^{c}=\bar{g}\right.$ and $R^{c}=\bar{R}$ ) by setting $\pi^{c}=(\bar{g}-\bar{R}) / \alpha \neq \bar{\pi}$. Thus, according to Figure 1 , the three targets are mutually exclusive: the first-best can not be reached, and we must stick to optimal control solutions (commitment regime). Unfortunately, the time-inconsistency problem of monetary 
policy gives the government incentives to cheat, as described in the following by the discretionary regime of the game.

In the discretionary regime, there is an inflation bias since the government attempts to generate seigniorage revenues by producing "inflation surprises", while in equilibrium such surprises are inconsistent with the rational behavior of citizens. To reproduce the commitment solution, several strategies to the problem of time-inconsistency were discussed in the literature, all of them distorting the government welfare function. Rogoff (1985) suggests appointing a "conservative" central banker (namely, who puts more emphasis than citizens on inflation deviations), while Walsh (1995) defends "contractual solutions". ${ }^{8}$ In this paper we implement a third solution, namely inflation targeting (which in our setup is however formally equivalent to the contractual approach of Walsh: Svensson 1997), and suppose that citizens impose an inflation target $\hat{\pi}$ to the government, who maximizes

$$
\hat{V}(\pi, g, R)=-\frac{1}{2}\left\{(\pi-\hat{\pi})^{2}+\lambda(g-\bar{g})^{2}+\mu(R-\bar{R})^{2}\right\} .
$$

The inflation target should be less than the "social" target $(\bar{\pi})$, to remove the inflation bias of monetary policy (this will be the case of the "optimal" target, as we see below), but here a general formulation, without constraining the range of values for $\hat{\pi}$, is adopted. ${ }^{9}$ In the discretionary regime with inflation targeting, the government maximizes (4) and we find the optimal inflation and deforestation values using first-order conditions: $(\pi-\hat{\pi})+\lambda(\alpha+\beta)(g-\bar{g})=0$ and $\lambda(g-\bar{g})+\mu(R-\bar{R})=0$. The equilibrium values for inflation and deforestation are now

$$
\begin{aligned}
& \pi^{d}=\hat{\pi}+(\alpha+\beta) \lambda \mu \eta^{d}(\bar{g}-\bar{R}-\alpha \hat{\pi}), \\
& R^{d}=\bar{R}+\lambda \eta^{d}(\bar{g}-\bar{R}-\alpha \hat{\pi})
\end{aligned}
$$

\footnotetext{
${ }^{8}$ In deterministic models like the present one, both contractual and conservative approaches can reproduce the commitment equilibrium, as it is well known. Nevertheless, in stochastic frameworks, a conservative central banker distorts the optimal response of monetary policy to supply shocks, and gives rise to a flexibility-versuscredibility tradeoff. On the contrary, an inflation targeting solution provides the commitment solution without distorting the response to shocks.

${ }^{9}$ Formally, the targeting approach is strictly equivalent to a crawling peg regime for the exchange rate. In such a regime, the domestic nominal exchange rate is fixed on a foreign anchor, and the domestic inflation rate equalizes the inflation rate on the anchorage currency. Thus, the foreign Central Bank on which domestic currency is anchored defines the inflation target. In countries being member of a monetary union, like WAEMU countries for example, the targeted inflation rate is defined by the board of Governors of the Union (the CFA franc being anchored on the Euro in WAEMU countries).
} 
where $\eta^{d} \equiv[\lambda+\mu(1+\alpha(\alpha+\beta) \lambda)]^{-1}$.

The optimal inflation target reproducing the commitment solution is $\hat{\pi}^{*}=\bar{\pi}-\lambda \mu \beta \eta^{c}(\bar{g}-\bar{R}-\alpha \bar{\pi})$, such as $\pi^{d}=\pi^{c}$ and $R^{d}=R^{c}$, and, as expected, is less than the "social" target $(\bar{\pi})$. In what follows, we conserve a more general formulation (without giving a certain value to the inflation target) and examine the implications of inflation targeting for environmental goals.

Equations (5a)-(5b) show that a tighter monetary policy (a lower inflation target $\hat{\pi}$ ) decreases the discretionary inflation rate $\left(\pi^{d}\right)$, but increases deforestation $\left(R^{d}\right)$. Consequently, we find a tradeoff between inflation and the environment: monetary policies that aim at reducing inflation are found to worsen environmental quality, by increasing deforestation rates. Notice that this tradeoff does not depend on the number of instruments available for government finance. Effectively, whatever the instruments to finance public expenditure, the optimal situation (which excludes corner solutions) will be to use slightly all available instruments. Therefore, reducing seigniorage will result in increasing the use of all instruments, including deforestation (see Appendix Al for a generalization of our model).

\section{Empirical evidence on the substitution effect between seigniorage and deforestation}

Our theoretical model exhibits a substitution effect between seigniorage and deforestation. This section tests this finding on a panel of developing countries. We first outline the econometric model and the data, before presenting the results.

\section{1/ The basic econometric specification and the data}

We estimate a dynamic panel data model with country and time fixed effects

$$
\text { Defor }_{i t}=a_{i}+a_{t}+\text { oDefor } r_{i t-1}+b_{0} \text { Seigniorage }_{i t}+\sum_{k=1}^{K} b_{k} X_{k ; i t}+\varepsilon_{i t} \text {. }
$$

$D_{\text {efor }}$ stands for the average deforestation rate, measured for $i=1, \ldots, N$ countries and $t=1, \ldots, T$ periods. $a_{i}$ is the intercept term for country $i$, capturing unobservable countries' structural characteristics that are period invariant (i.e. long term climatic and geographical characteristics), while $a_{t}$ stands for the fixed effect for period $t$ and accounts for unobservable periods' characteristics that are country invariant (i.e. international price 
movements). $\rho$ catches inertia in the dynamics of deforestation process. Coefficient $b_{0}$ measures the marginal effect of Seigniorage, $b_{k}$, with $k=1, \ldots, K$, are the coefficients to be estimated for the $K$ control variables, and $\varepsilon_{i t}$ is the idiosyncratic error.

The left-hand side variable is the average deforestation rate over the considered period (Defor). Data come from FAOSTAT, who compiles forest stocks between 1990 and 2010. Our interest variable is the seigniorage, computed as the change in reserve money over GDP for the considered period (Aisen \& Veiga 2008). We consider the average variation in reserves over GDP (Seigniorage1) and, alternatively and to account for extreme values, the median value of variations in reserves over GDP (Seigniorage2).

We account for two groups of control variables $X_{k}$, namely close to the theoretical model (first group), and inspired by the related literature (second group). In the first group, to account for the fact that an increase in public spending is detrimental to the forest (public spending raises the need for additional resources), we introduce two variables, namely the ratio of general government consumption to GDP (GovSpend), and the ratio of the total debt service to exports (DebtBurden). Appendix A2 presents variables' definitions and sources.

The second group of control variables is inspired by the literature on the determinants of deforestation. First, in accordance with several contributions (Barbier 2004; Culas 2007), we control for an Environmental Kuznets Curve (EKC) for deforestation. Consequently, we seize a nonlinear influence of per-capita income $(G D P P C)$ on deforestation, using a quadratic form (Squared GDPPC). Second, the population size has no clear-cut effect on deforestation, since it can either reduce (by raising the demand for forest products, Foster \& Rosenzweig 2003), or accelerate it (the population pressure increases the conversion of forest into arable lands and the demand for fuel wood, Cropper \& Griffiths 1994); we consider the total population (TotPop). Third, we control for the effect of economic growth (Growth) on deforestation. Rudel \& Roper (1997) describe a resource-consuming economic growth process, which may be compensated by reallocation effects between agricultural and industrialized sector. Therefore, we do not sign a priori the effect of Growth on deforestation. Fourth, following Bhattarai \& Hammig (2001), to account for the fact that better institutions preserve forests, we rely on two measures of the quality of institutions, namely the government stability (Govstab) and internal conflict (IntConf) as measured by the PRS group through the ICRG (Ferreira \& Vincent 2010). In both cases, an increase signals an improvement and is expected 
to reduce deforestation. Fifth, we consider the real exchange rate (Reer) to control for the competitiveness of the export sector. ${ }^{10}$ In line with previous findings (Arcand et al. 2008), a real appreciation of the local currency (an increase in Reer) is expected to reduce deforestation. The intuition is that it slows down land clearing for the agricultural export sector expansion and penalizes the profitability of logging activities for exports. Sixth, the instability of the real exchange rate (ReerInst) captures the potential macroeconomic instability in developing countries; thus, we expect a negative effect. Finally, we also take the real interest rate (IntRate) into account to capture the Hotelling rule, i.e. a decrease in the real interest rate dampens forest depletion; nevertheless, this effect could be contradicted since the interest rate also affects the user cost of capital in deforestation activities (Farzin 1984). However, since deforestation activities are deemed to be labor-intensive, the former effect is potentially more important; this intuition is not rejected in the empirical literature dedicated to the drivers of timber harvests (Ferreira \& Vincent 2010). In particular, monetary policy is considered not to impact real interest rates, from the perspective of the neutrality of money in the long-run and the privileged influence of the international environment (i.e. international real interest rates) on domestic real interest rates.

For each of the 79 countries to be potentially included in the sample (Appendix A3 presents the list of countries), four observations are available for the following periods: 1990-1994, 1995-1999, 2000-2004 and 2005-2010; period-averages are computed to hinder short-term fluctuations. ${ }^{11}$

The Arellano and Bond's GMM estimator for dynamic panel is implemented for two reasons (Arellano \& Bond 1991). First, the OLS estimator is inconsistent since the lagged dependent variable is introduced besides country fixed-effects (Nickell 1981). Second, the GMM estimator controls for the potential endogeneity of the Seigniorage variables due to measurement error, reverse causality or omission of pertinent variable. The equations are estimated in first-differences and the lagged levels of the explanatory variables are used as

\footnotetext{
${ }^{10}$ Note that Reer is computed without taking into account oil exporters in the calculation of the weighting of the main trade partners. We report that introducing oil exporters does not change our results.

${ }^{11}$ The lower bound time period for our sample can be subject to debate, as FAO Production Yearbook data on deforestation are available since 1970. Considering the time span 1970-2005, we were exhibiting in the previous version of our manuscript a significant and robust substitution effect on deforestation and seigniorage. However, this series is less reliable than the estimates of deforestation from FAOSTAT, which rely on the recent Forest Resource Assessment (FRA 2010). To make our analysis more convincing, we draw upon FAOSTAT data which are available for the period 1990-2010. Although these estimates span just 20 years, they are the best available cross-country data on deforestation. We restrict to FAO Production Yearbook data only for providing instruments of the lagged endogenous variable.
} 
instruments. $^{12}$ The validity of the instruments is tested by the Sargan/Hansen overidentification test and by the second order serial correlation test $\operatorname{AR}(2)$, where the null hypothesis is that the error term does not exhibit auto-correlation. At last, to deal with the problem of instruments proliferation, the matrix of instruments is collapsed to ensure that the number of instruments does not exceed the number of countries (Roodman 2009).

\section{2/ The econometric results}

Equations [1] and [1bis] in Table 4 measure the influence of seigniorage on deforestation, by alternatively relying on Seigniorage1 and Seigniorage 2 as interest variables. We estimate a parsimonious model under the hypothesis of the Environmental Kuznets Curve (EKC) augmented by the size of the population in log, and controlling by lagged deforestation. Equation [1] exhibits a significant and negative effect of average seigniorage on deforestation. This result holds when accounting for the median, instead of the average, seigniorage in regression [1bis]. Consequently, we emphasize a tradeoff between deforestation and seigniorage, consistent with our theoretical model.

Capitalizing on benchmark Equations [1] and [1bis], we explore in Table 4 the robustness of the substitution effect between deforestation and seigniorage to the introduction of several main determinants of deforestation. Following our theoretical model, we account for government spending and the debt service in Equation [2]. Equation [3] introduces the medium-term economic cycle, as measured by the GDP per capita growth. Given its importance, we focus on institutional quality in three alternative specifications, namely Equations [4], [4bis] and [5]. In both Equations [4] and [4bis] we account for the government stability, while equation [5] controls for the occurrence of internal conflicts. In addition, Equation [4bis] deals with the potential weak instruments problem, by adding an external instrument, namely the number of central bank governors' turnover used in Dreher et al. (2008, 2010). We assume that this proxy of the central bank independence influences deforestation exclusively through seigniorage. In Equation [6] we introduce relative prices, measured by the real effective exchange rate, and the macro-economic instability, measured by the instability of the real effective exchange rate, as additional determinants of deforestation. Finally, in Equation [7], we test the impact of the real interest rate.

\footnotetext{
${ }^{12}$ The lagged deforestation rate and the seigniorage are considered as predetermined and the other variables as strictly exogenous.
} 
Regarding control variables, the positive and significant coefficient of one-period lagged deforestation does not reject the existence of an inertia phenomenon in deforestation process. Moreover, the presence of an EKC is supported in most cases. When significant, population increases deforestation, as expected. ${ }^{13}$ Even more importantly, in several specifications public spending and the debt service have a positive effect on deforestation, which may be consistent with the conclusions of Kahn \& McDonald (1995), defending debt alleviations as a mean to reduce the pressure on forests (although "environmental debt alleviations" are of low magnitude). Economic growth slows down forest harvesting, one possible explanation being that economic growth mirrors structural changes occurring in the manufactured or services sectors. Irrespective of the way they are measured (see Equations [4], [4bis] and [5]), better institutions allow preserving the forest. A real appreciation dampens deforestation, contrary to the real exchange rate instability which favors it (Equation [6]). Finally, the impact of the real interest rate on deforestation is not significant (the p-value equals 0.16 ), while the effect of seigniorage still prevails (Equation [7]), showing that the effect of monetary policy on deforestation is not channeled through the real interest rate, but through seigniorage.

\footnotetext{
${ }^{13}$ We ran Equation [1] by taking population growth into account besides total population; however, this variable did not add any explanatory power to our model.
} 
Table 4 - Empirical evidence for a tradeoff between deforestation and seigniorage

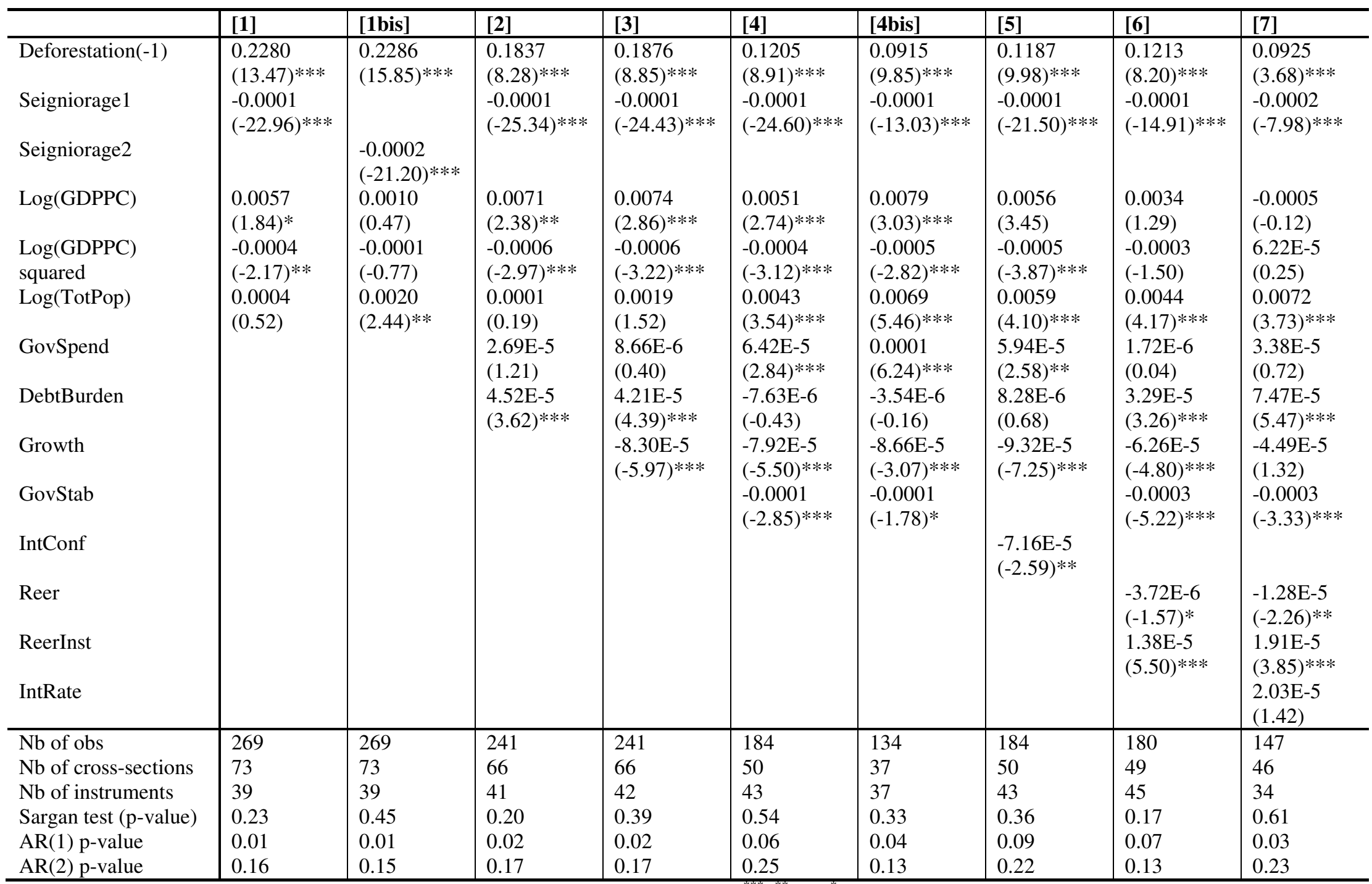

Note: $t$-statistics in brackets are robust to cross-section heteroskedasticity in the disturbances. , , and " show significance at the 1,5 and $10 \%$ level respectively. 
Most importantly, when accounting for all these crucial determinants of deforestation, we can clearly isolate a negative and significant link between seigniorage and deforestation. In addition to its persistence in both sign and significance when progressively adding up determinants of deforestation, this effect remains robust for different measures of seigniorage (average or median values) or when adding to the internal instruments inherent to the GMM method an external instrument, namely the central bank governors' turnover. Consequently, our estimations emphasize a statistically significant tradeoff between seigniorage and deforestation, as predicted by our theoretical analysis.

In addition to its negative sign, it may be worth providing an estimation of the magnitude of this negative effect. On the basis of equation [1], the avoided deforestation rate generated by a one standard deviation increase in seigniorage reaches approximately one tenth of the annual average deforestation rate over 1990 to 2010. This result confirms that the environmental sacrifice ratio of inflation-fighting policies is not negligible, and that there exists a tradeoff between macroeconomic goals and environmental objectives, as depicted by Figure 1, which needs to be further addressed.

\section{Solving the environmental versus disinflation tradeoff}

This tradeoff can be very unpleasant both from LDCs and worldwide perspectives. On the one hand, low inflation is often necessary for economic stability and inflation-fighting policies are often considered as a prerequisite to obtain international aid: are LDCs condemned to pay inflation cuts with natural resources damages? On the other hand, deforestation exerts international spillover effects. Thus, inflation-fighting policies conducted in LDC can have harmful effects from a worldwide welfare perspective. In this section, we search for an institutional setup that can avoid making such a choice between low-inflation and environmental policies.

To address this question, suppose that, in the theoretical model of section 2, the commitment equilibrium (which can be replicated by the optimal inflation target in the discretionary regime) is optimal from the domestic citizens' perspective, but, because of international spillovers, is not optimal from the Rest-of-the-World point of view. We can assume, for example, that the deforestation rate $R^{d}$ is too high relative to global environmental objectives on a worldwide scale. Thus, we search for a solution in the form of a transfer scheme that could be implemented by an International Agency, which acts as a 
(worldwide) social planner. Acting as the "Principal", the International Agency can deliver a contract to domestic government (the "Agent"), in order to reduce deforestation. To achieve this goal, the Principal transfers to the Agent a basic allowance $F$, which is reduced by an amount proportional to resource depletion. Thus, the financial transfer is $F-\omega R$, where $\omega$ is the penalty per unit of deforestation. ${ }^{14}$ Consequently, the government maximizes the following welfare function, with $\hat{\pi}$ the government's inflation target

$$
\tilde{V}(\pi, g, R)=-\frac{1}{2}\left\{(\pi-\hat{\pi})^{2}+\lambda(g-\bar{g})^{2}+\mu(R-\bar{R})^{2}\right\}+F-\omega R .
$$

We find the optimal inflation and deforestation values using the first-order conditions: $(\pi-\hat{\pi})+\lambda(\alpha+\beta)(g-\bar{g})=0$ and $\lambda(g-\bar{g})+\mu(R-\bar{R})+\omega=0$. The new equilibrium values under the discretionary regime are easily derived

$$
\begin{aligned}
& \tilde{\pi}(\omega)=\hat{\pi}+(\alpha+\beta) \lambda \eta^{d}[\mu(\bar{g}-\bar{R}-\alpha \hat{\pi})+\omega], \\
& \tilde{R}(\omega)=\bar{R}+\eta^{d}[\lambda(\bar{g}-\bar{R}-\alpha \hat{\pi})-(1+\alpha(\alpha+\beta) \lambda) \omega] .
\end{aligned}
$$

As expected, resource harvesting $\widetilde{R}(\omega)$ negatively depends on the penalty $\omega$ in relation (8b); moreover, notice that the "environmental penalty" positively affects the equilibrium inflation rate in relation (8a). As a result, the rate of inflation under the contractual regime will be higher than under the domestic discretionary regime: $\tilde{\pi}(\omega)=\pi^{d}+(\alpha+\beta) \lambda \eta^{d} \omega \geq \pi^{d}$, since $\omega \geq 0$. This property reflects, once again, the substitutable character of inflation and environmental quality in the model.

We then search for an optimal penalty $\left(\omega^{*}\right)$, namely the value of the penalty that maximizes welfare from a worldwide perspective. Suppose that the only difference between the citizens' goal $(V)$ and the social planner's goal $(W)$ is that the latter defends lower deforestation, since the social planner internalizes the externality ${ }^{15}$

\footnotetext{
${ }^{14}$ This contract is designed like a transfer scheme for "avoided deforestation", with a reward proportional to efforts in avoiding deforestation. In equilibrium we suppose that $F=\omega^{*} R$, where $\omega^{*}$ is the optimal penalty to be defined below, such as the budget of the International Authority is balanced (in a multi-country model, we would have $\sum_{i=1}^{n} F_{i}=\sum_{i=1}^{n} \omega_{i}^{*} R_{i}$, with $i=(1, n)$ the index of country $\left.i\right)$.

${ }^{15}$ One might also put forward the idea that $\bar{R}$ is too high relative to the optimal rate $\hat{R}$, since governments are short-sighted and adopt deforestation rates that are suboptimal from a long-term welfare perspective.
} 


$$
W(\pi, g, R)=-\frac{1}{2}\left\{(\pi-\bar{\pi})^{2}+\lambda(g-\bar{g})^{2}+\mu(R-\hat{R})^{2}\right\}, \text { where } \hat{R}<\bar{R}
$$

Acting as the leader in the Stackelberg delegation game, the Principal internalizes the equilibrium values of seigniorage $\tilde{\pi}(\omega)$ and resource extraction $\tilde{R}(\omega)$ in (8a-b), and maximizes $W(\omega)$. Thus, the optimal penalty $\omega^{*}$ is solution of $\frac{d W(\omega)}{d \omega}=0$ (as $\left.\frac{d^{2} W(\omega)}{d \omega^{2}}<0\right)$

$$
\frac{d \pi}{d \omega}(\pi-\bar{\pi})+\lambda\left(\alpha \frac{d \pi}{d \omega}+\frac{d R}{d \omega}\right)(g-\bar{g})+\mu \frac{d R}{d \omega}(R-\hat{R})=0,
$$

namely, after some simple algebra

$$
\omega^{*}=\mu(\bar{R}-\hat{R})-(\alpha+\beta) \lambda\left[\frac{\hat{\pi}-\bar{\pi}+\beta \lambda \mu \eta^{d}(\bar{g}-\hat{R}-\alpha \hat{\pi})}{1+(\alpha+\beta)\left(\alpha+\beta \lambda \eta^{d}\right) \lambda}\right] .
$$

Since $\alpha \beta \lambda \mu \eta^{d}<1$, notice that: $\frac{d \omega^{*}}{d \hat{\pi}}<0$. Thus, to maximize worldwide welfare, the Principal must increase the optimal penalty $\omega^{*}$ following the adoption of a tighter monetary policy (a lower inflation target $\hat{\pi}$ ). Therefore, the optimal rewards for "avoided deforestation" are inflation-contingent. Let us provide the intuitive explanation of this result. In equation (11), the optimal rewards depend on three terms. The first term relates to the correction of the environmental bias between the preferences of the Agent and the Principal $(\bar{R}-\hat{R})$. The second term refers to the effect of the inflation target $(\hat{\pi}-\bar{\pi})$. Since a lower inflation target induces government to use intensively natural resources, the optimal penalty $\omega^{*}$ must be increased as the inflation target decreases. The third term is linked to the implicit target for public spending that results from the environmental and inflation targets, namely: $\hat{g} \equiv \hat{R}+\alpha \hat{\pi}$ . If $\hat{g}>\bar{g}$, there is an extra-incentive to cheat for the Government, because the external inflation and environmental targets overpass the internal public spending target; the optimal penalty must correct this incentive. Finally, notice that this term depends on the timeinconsistency of monetary policy $(\beta)$; without time-inconsistency of monetary policy $(\beta=0)$, the penalty simply reduces to: $\omega^{*}=\mu(\bar{R}-\hat{R})-\frac{\alpha \lambda \hat{\pi}}{1+\alpha^{2} \lambda}$.

We are now able to compute the effect of $\hat{\pi}$ on the optimal rate of deforestation 


$$
\begin{aligned}
& \frac{d \tilde{\pi}\left(\omega^{*}\right)}{d \hat{\pi}}=1-\eta^{d}(\alpha+\beta) \lambda\left(\alpha \mu-\frac{d \omega^{*}}{d \hat{\pi}}\right)=\frac{1}{1+(\alpha+\beta)\left(\alpha+\beta \lambda \eta^{d}\right) \lambda}>0, \\
& \frac{d \tilde{R}\left(\omega^{*}\right)}{d \hat{\pi}}=-\eta^{d}\left[\alpha \lambda+(1+\alpha(\alpha+\beta) \lambda) \frac{d \omega^{*}}{d \hat{\pi}}\right]=\frac{\beta \lambda \eta^{d}}{1+(\alpha+\beta)\left(\alpha+\beta \lambda \eta^{d}\right) \lambda} \geq 0 .
\end{aligned}
$$

The system (12a-b) presents a very interesting result. Contrary to the case $\omega=0$ in section 2, where a tighter monetary target was increasing deforestation, a lower inflation target $d \hat{\pi}<0$ reduces deforestation in relation $(12 \mathrm{~b})$, or at least leaves it unchanged provided there is no time inconsistency $\left(d \tilde{R}\left(\omega^{*}\right) / d \hat{\pi}=0\right.$ if $\left.\beta=0\right)$.

The intuitive explanation of this result is the following. In relation (8b), a tighter inflation target reduces seigniorage and induces the Government to increase deforestation revenues (negative direct effect). To circumvent this incentive, the penalty on deforestation must be increased, thus reducing the equilibrium rate of deforestation (positive indirect effect). The net effect of the inflation target on deforestation is the sum of these direct and indirect effects.

Without time-inconsistency of monetary policy, there is no inflation bias, and the penalty on deforestation must be increased in order to exactly offset the effect of the inflation target, which leaves unchanged deforestation in equilibrium. In fact, without time inconsistency, the optimal inflation target should be equal to the "social" target $(\hat{\pi}=\bar{\pi})$, and the solution of the game is simply the commitment solution (3a-b) of section 2, with $\hat{R}$ replacing $\bar{R}$ ( $\tilde{\pi}=\alpha \lambda \mu \eta^{c}(\bar{g}-\alpha \bar{\pi}-\hat{R})$ and $\left.\tilde{R}=\hat{R}+\lambda \eta^{c}(\bar{g}-\alpha \bar{\pi}-\hat{R})\right)$.

With time-inconsistency, on the contrary, the commitment solution can no longer be reached, and, as we have seen, there is an incentive to cheat. Thus, following a cut in the inflation target, the optimal penalty must be specified in order to solve both the problem of the incentive to rely too heavily on deforestation revenues (for public finance needs) and the problem of the incentive to cheat (because of time-inconsistency), as depicted by the additional (third) term in the optimal penalty (11). This additional term ensures that the indirect effect of the penalty will exceed the direct effect of the inflation target in equation (8b). Therefore, the net effect of the inflation target on deforestation becomes positive, namely, a reduction of the inflation target gives rise to a reduction in deforestation. 
Consequently, subsidizing efforts in strengthening the quality of environment may upturn the positive association between a tighter monetary policy and deforestation. In other words, under the "optimal penalty" $\left(\omega^{*}\right)$, the conflict between disinflation and environment vanishes; in some sense, the environmental transfer scheme is able to overcome the "triangle of impossibility" depicted in Figure 1.

Remark that this institutional design, involving the interference of an International Agency that implements a transfer scheme to limit natural resource exploitation, is closely related to several advances about the implementation of "rewards" for countries combating the climate change, namely the design of policy devices and the estimation of GHG abatement costs related to forests.

On the one hand, Kahn \& McDonald (1995) outline a significant positive association between public debt and deforestation in LDCs, and defend debt alleviations as a mean to reduce the pressure to deforest. Several countries, like Indonesia, have recently engaged in "debt-for-nature" swaps for preventing future deforestation. ${ }^{16}$ Moreover, during the CoP 11 of the UNFCCC held in Montreal in 2005, several countries led by Papua New Guinea have put forward the role of forests in mitigating GHG emissions and requested an agenda aiming at "Reducing emissions from deforestation in developing countries" (REDD). The REDD mechanism specifies that countries that curb deforestation and forest degradation below a baseline receive either monetary transfers or are granted tradable allowances. ${ }^{17}$ This appears to be a noticeable advance, since forests were dropped out of the Kyoto Protocol. Finally, notice also that developed countries have pledged substantial amounts to fund a program to curb deforestation in the 2009 Copenhagen meeting (CoP 15).

On the other hand, the Stern Review argued that the cost of reducing emissions from deforestation may be relatively low: the opportunity cost of ceasing deforestation ranges between 5 and 10 billion USD per year (Stern 2007, chap.9). More recently, it has been

\footnotetext{
${ }^{16}$ Debt-for-nature swaps have been used as a tool for preserving environmental quality. They can take many different forms (Hansen 1989) and are designed to cutting-off foreign debt against an engagement to preserve the environment.

${ }^{17}$ REDD programs are aimed at generating transfer flows of resources to reduce global emissions from deforestation and forest degradation (see, for example, Combes Motel et al. 2009). The REDD scheme recommends that developed countries pay developing countries for $\mathrm{CO} 2$ emissions saved through avoided deforestation. In Copenhagen an updated version of REDD was put forward, called REDD+ (Reduction of Emissions from Deforestation and forest Degradation "plus" Conservation). Even closer to our proposition, a multi-donor trust fund was established in July 2008, allowing donors to pool resources and providing funding to activities towards this Program.
} 
established that the majority of GHG abatement opportunities are located in developing countries, which are endowed with the highest opportunities in the forestry and agricultural sectors (Nauclér \& Enkvist 2009).

\section{Conclusion}

In the context of climate change and international agreements to reduce GHG emissions, the fight against deforestation gained new interest. This paper bridges a gap between two aspects of economic policies in developing countries that are usually considered in isolation, namely natural resources depletion, i.e. deforestation, and monetary policies. Indeed, including environmental objectives in Governments' preoccupations and considering the potential impact of macroeconomic objectives on the environment can provide a way to impede the deforestation process that affected developing countries in the last decades.

In developing countries with an important forest area, deforestation revenues and seigniorage are two important resources for Governments. Consequently, we develop a theoretical model showing that Governments can trade off revenues generated by deforestation with seigniorage. The evidence illustrated by the econometric analysis, performed on a sample of developing countries, corroborates the existence of an arbitrage between deforestation revenues and seigniorage, emphasizing that the latter is an important driver of the deforestation process. To put it differently, macroeconomic policies that restrict seigniorage revenues by fighting inflation (such as, for example, IMF's recommendations for tightened monetary policies, including inflation targeting) can reduce the efficiency of environmental policies aimed at promoting sustainable forest management, because they create an incentive for Governments to increase the rate of resource exploitation for obtaining missing revenues. This idea receives support in the survey by López (2006, p.157) showing that countries under structural adjustments programs underinvested in their environmental assets.

One way to avoid deforestation in low-inflation countries is to allow for an International Agency to subsidy forest protection policies. A transfer scheme defining inflation-contingent rewards for "avoided deforestation" can be a way for implementing a form of "win-win strategy" (similar to the debt-for-nature swaps), by removing the temptation for governments to over-deplete forests. Sketching the operational design for such a mechanism is beyond the scope of this paper. However, several experiences can help 
shedding some light on the relevance of the mechanism. For instance, Cassimon et al. (2011) identify several shortcomings among which additionality. Moreover, Barbier (2011) draws attention on the need to find new sources of funding to make REDD like mechanisms more effective. At last, recent estimations of the size of the transfer have already been released: Angelsen et al. (2009) suggest that an amount of 2 billion USD per year, gradually increasing within 5 years to 10 billion, may be appropriate to support REDD funding. 


\section{References}

Aisen, A. \& Veiga, F.J., 2008. The political economy of seigniorage. Journal of Development Economics, 87(1), p.29-50.

Alesina, A. \& Tabellini, G., 1987. Rules and discretion with noncoordinated monetary and fiscal policies. Economic Inquiry, 25(4), p.619-630.

Angelsen, A. et al., 2009. Reducing Emissions from Deforestation and Forest Degradation (REDD): an options assessment report. Prepared for the Government of Norway, Meridian Institute. Available at: http://www.redd-oar.org/links/REDD-OAR_en.pdf.

Angelsen, A. \& Kaimowitz, D., 1999. Rethinking the Causes of Deforestation: Lessons from Economic Models. The World Bank Research Observer, 14(1), p.73-98.

Arcand, J.-L., Guillaumont, P. \& Guillaumont Jeanneney, S., 2008. Deforestation and the real exchange rate. Journal of Development Economics, 86(2), p.242-262.

Arellano, M. \& Bond, S., 1991. Some Tests of Specification for Panel Data: Monte Carlo Evidence and an Application to Employment Equations. The Review of Economic Studies, 58(2), p.277-297.

Barbier, E.B., 2004. Agricultural Expansion, Resource Booms and Growth in Latin America: Implications for Long-run Economic Development. World Development, 32(1), p.137157.

Barbier, E.B., 2011. The policy challenges for green economy and sustainable economic development. Natural Resources Forum, 35(3), p.233-245.

Barro, R.J., 1990. Government Spending in a Simple Model of Endogeneous Growth. The Journal of Political Economy, 98(5), p.S103-S125.

Barro, R.J. \& Gordon, D.B., 1983. Rules, discretion and reputation in a model of monetary policy. Journal of Monetary Economics, 12(1), p.101-121.

Beckerman, W., 1992. Economic growth and the environment: Whose growth? whose environment? World Development, 20(4), p.481-496.

Bhattarai,_M. \& Hammig, M., 2001. Institutions and the Environmental Kuznets Curve for deforestation: a crosscountry analysis for Latin America, Africa and Asia. World Development, 29(6), p.995-1010.

Bovenberg, A.L. \& Smulders, S., 1995. Environmental quality and pollution-augmenting technological change in a two-sector endogenous growth model. Journal of Public Economics, 57(3), p.369-391.

Cagan, P., 1956. The monetary dynamics of hyperinflation. In M. Friedman, ed. Studies in the Quantitative Theory of Money. Chicago: University of Chicago Press, p. 25-117.

Calvo, G.A., 1978. On the Time Consistency of Optimal Policy in a Monetary Economy. Econometrica, 46(6), p.1411-1428.

Cassimon, D., Prowse, M. \& Essers, D., 2011. The pitfalls and potential of debt-for-nature swaps: A US-Indonesian case study. Global Environmental Change, in press.

Chomitz, K.M., 2007. At loggerheads?: agricultural expansion, poverty reduction, and environment in the tropical forests, Washington D.C.: World Bank Publications. Available

at: http://econ.worldbank.org/WBSITE/EXTERNAL/EXTDEC/EXTRESEARCH/EXTP RRS/EXTTROPICALFOREST/0,,menuPK:2463898 pagePK:64168092 piPK:64168 088 theSitePK:2463874,00.html.

Combes Motel, P., Pirard, R. \& Combes, J.L., 2009. A methodology to estimate impacts of domestic policies on deforestation: Compensated Successful Efforts for «avoided deforestation » (REDD). Ecological Economics, 68(3), p.680-691.

Combes Motel, P., Choumert, J., Minea, A. \& Sterner, T., 2013. Explorations in the Environment-Development dilemma. Environmental and Resource Economics, forthcoming. 
Cropper, M. \& Griffiths, C., 1994. The interaction of population growth and environmental quality. The American Economic Review, 84(2), p.250-254.

Culas, R.J., 2006. Debt and Deforestation. Journal of Developing Societies, 22(4), p.347 -358.

Culas, R.J., 2007. Deforestation and the environmental Kuznets curve: An institutional perspective. Ecological Economics, 61(2-3), p.429-437.

Denman, K.L. et al., 2007. Chapter 7. Couplings Between Changes in the Climate System and Biogeochemistry. In S. Solomon et al., ed. Climate Change 2007: the physical science basis. Contribution of Working Group I to the Fourth Assessment Report of the Intergovernmental Panel on Climate Change. Cambridge UK and New York, NY: Cambridge University Press.

Dreher, A., Sturm, J.-E. \& De Haan, J., 2010. When is a central bank governor replaced? Evidence based on a new data set. Journal of Macroeconomics, 32(3), p.766-781.

Dreher, A., Sturm, J.-E. \& De Haan, J., 2008. Does high inflation cause central bankers to lose their job? Evidence based on a new data set. European Journal of Political Economy, 24(4), p.778-787.

FAO, 2010. Appendix 2 - Terms and definitions used in FRA 2010. In Global Forest Resources Assessment 2010. Main Report. FAO Forestry Paper. Rome: FAO, p. 209216. Available at: http://www.fao.org/forestry/fra/fra2010/en/.

Farzin, Y.H., 1984. The Effect of the Discount Rate on Depletion of Exhaustible Resources. Journal of Political Economy, 92(5), p.841-851.

Ferreira, S. \& Vincent, J.R., 2010. Governance and Timber Harvests. Environmental and Resource Economics, 47(2), p.241-260.

Foster, A.D. \& Rosenzweig, M.R., 2003. Economic Growth and the Rise of Forests. The Quarterly Journal of Economics, 118(2), p.601-637.

Fullerton, D. \& Kim, S.-R., 2008. Environmental investment and policy with distortionary taxes, and endogenous growth. Journal of Environmental Economics and Management, 56(2), p.141-154.

Geist, H.J. \& Lambin, E.F., 2001. What drives tropical deforestation? A meta-analysis of proximate and underlying causes of deforestation based on subnational case study evidence, Louvain-la-Neuve: LUCC International Project Office - University of Louvain. Available at: http://www.pikpotsdam.de/members/cramer/teaching/0607/Geist_2001_LUCC_Report.pdf.

Gordon, R. \& Li, W., 2009. Tax structures in developing countries: Many puzzles and a possible explanation. Journal of Public Economics, 93(7-8), p.855-866.

Grossman, G.M. \& Krueger, A.B., 1995. Economic Growth and the Environment. The Quarterly Journal of Economics, 110(2), p.353-377.

Hansen, S., 1989. Debt for nature swaps -- Overview and discussion of key issues. Ecological Economics, 1(1), p.77-93.

Houghton, R.A., 2005. Chapter 1. Tropical Deforestation as a source of Greenhouse gas emissions. In P. Moutinho \& S. Schwartzman, ed. Tropical Deforestation and Climate Change. Belém and Washington DC: IPAM - Amazon Institute for Environmental Research and Environmental Defense, p. 13-22. Available at: http://www.environmentaldefensefund.org/sites/default/files/4930_TropicalDeforestati on_and_ClimateChange.pdf\#page $=13$.

IPCC, 2007. Climate Change 2007: the physical science basis. Contribution of Working Group I to the Fourth Assessment Report of the Intergovernmental Panel on Climate Change S. Solomon et al., ed., Cambridge UK: Cambridge University Press.

Kahn, J.R. \& McDonald, J.A., 1995. Third-world debt and tropical deforestation. Ecological Economics, 12(2), p.107-123. 
Laurance, W.F. et al., 2012. Averting biodiversity collapse in tropical forest protected areas. Nature, 489(7415), p.290-294.

Le, T.M., Moreno-Dodson, B. \& Bayraktar, N., 2012. Tax Capacity and Tax Effort: Extended Cross-Country Analysis from 1994 to 2009, Rochester, NY: Social Science Research Network. Available at: http://papers.ssrn.com/abstract=2167186.

López, R., 2006. Structural Adjustment and Sustainable Development. In R. López \& M. A. Toman, ed. Economic Development and Environmental Sustainability: New Policy Options. Oxford: Oxford University Press, p. 154-177.

Meadows, D.H., Randers, J. \& Meadows, D.L., 2005. The Limits to Growth: The 30-year Update Revised edition., London: Earthscan.

De Mooij, R.A., Keen, M. \& Parry, I.W.H. ed., 2012. Fiscal Policy to Mitigate Climate Change: A Guide for Policymakers, Washington D.C.: International Monetary Fund.

Nauclér, T. \& Enkvist, P.A., 2009. Pathways to a Low-Carbon Economy. Version 2 of the global greenhouse gas abatement cost curve, Mac Kinsey and Company. Available at: http://www.mckinsey.com/clientservice/ccsi/pathways_low_carbon_economy.asp.

Nepstad, D. et al., 2009. The End of Deforestation in the Brazilian Amazon. Science, 326(5958), p.1350-1351.

Nickell, S., 1981. Biases in Dynamic Models with Fixed Effects. Econometrica, 49(6), p.1417-1426.

Robalino, J. \& Herrera, L.D., 2010. Trade and deforestation: A literature review, World Trade Organization - Economic Research and Statistics Division. Available at: http://www.econstor.eu/handle/10419/57620.

Rogoff, K., 1985. The Optimal Degree of Commitment to an Intermediate Monetary Target. The Quarterly Journal of Economics, 100(4), p.1169-1189.

Roodman, D., 2009. A Note on the Theme of Too Many Instruments. Oxford Bulletin of Economics and Statistics, 71(1), p.135-158.

Rudel, T.K. \& Roper, J., 1997. The paths to rain forest destruction: Crossnational patterns of tropical deforestation, 1975-1990. World Development, 25(1), p.53-65.

Stern, N.H., 2007. The economics of climate change: the Stern review, Cambridge University Press.

Svensson, L.E.O., 1997. Optimal Inflation Targets, "Conservative" Central Banks, and Linear Inflation Contracts. The American Economic Review, 87(1), p.98-114.

Walsh, C.E., 1995. Optimal Contracts for Central Bankers. The American Economic Review, 85(1), p.150-167.

Van der Werf, G.R. et al., 2009. CO2 emissions from forest loss. Nature Geoscience, 2(11), p.737-738. 


\section{Appendix A1. The model with three instruments}

We consider in this Appendix a model with an additional financing source, namely income taxes or taxes on a mineral resource $(\tau)$. Consequently, the welfare function becomes

$$
\hat{V}(\pi, g, R)=-\frac{1}{2}\left\{(\pi-\hat{\pi})^{2}+\lambda(g-\bar{g})^{2}+\mu(R-\bar{R})^{2}+v(\tau-\bar{\tau})^{2}\right\},
$$

where the tax target $\bar{\tau}$ was already explained in the main text. The maximization of the welfare function under the budget constraint

$$
g=R+\alpha \pi+\beta\left(\pi-\pi^{e}\right)+\phi \tau, \alpha>0 ; \beta \geq 0,
$$

yields the following discretionary solution

$$
\begin{aligned}
& \pi^{d}=\hat{\pi}+(\alpha+\beta) \lambda \mu \eta^{1}(\bar{g}-\bar{R}-\phi \bar{\tau}-\alpha \hat{\pi}) \\
& R^{d}=\bar{R}+\lambda \eta^{1}(\bar{g}-\bar{R}-\phi \bar{\tau}-\alpha \hat{\pi}) \\
& \tau^{d}=\bar{\tau}+\frac{\lambda \mu \phi \eta^{1}}{v}(\bar{g}-\bar{R}-\phi \bar{\tau}-\alpha \hat{\pi})
\end{aligned}
$$

where: $\eta^{1} \equiv\left[\lambda+\mu\left(1+\frac{\phi^{2}}{v}+\alpha(\alpha+\beta) \lambda\right)\right]^{-1}$.

Equations (A3a-c) show that a tighter monetary policy (a lower inflation target $\hat{\pi}$ ) decreases the discretionary inflation rate $\left(\pi^{d}\right)$, but increases the rate of resource depletion $\left(R^{d}\right)$ and the tax rate $\left(\tau^{d}\right)$. Consequently, we still find a tradeoff between disinflation and natural resources.

Assume in the following that $v=0$, to find the results in the main text, and also that the government is able to find an alternative resource to finance public spending: such a resource may come from an exceptional tax or from a direct transfer from abroad, i.e. aid, debt relief, etc. We model this additional resource, which is a substitute for transfers rewarding avoided deforestation, by $\omega \equiv \phi \tau$. In the following, we will show that such a resource cannot modify the tradeoff between disinflation and deforestation. The maximization of (a1) leads to unchanged first order conditions, $(\pi-\hat{\pi})+\lambda(\alpha+\beta)(g-\bar{g})=0$ and $\lambda(g-\bar{g})+\mu(R-\bar{R})=0$, and only the government's budget constraint is relieved $g=R+\alpha \pi+\beta\left(\pi-\pi^{e}\right)+\omega$, with 
$\omega \equiv \phi \tau$ the additional resource. Thus, the new equilibrium values under the discretionary regime are easily derived

$$
\begin{aligned}
& \tilde{\pi}(\omega)=\hat{\pi}+(\alpha+\beta) \lambda \mu \eta^{d}(\bar{g}-\bar{R}-\alpha \hat{\pi}-\omega), \\
& \tilde{R}(\omega)=\bar{R}+\lambda \eta^{d}(\bar{g}-\bar{R}-\alpha \hat{\pi}-\omega) .
\end{aligned}
$$

Remark that both variables negatively depend on the additional resource $\omega$. Adopting the same strategy as in the main text, we find the optimal value of $\omega$ which maximizes

$$
W(\pi, g, R)=-\frac{1}{2}\left\{(\pi-\bar{\pi})^{2}+\lambda(g-\bar{g})^{2}+\mu(R-\hat{R})^{2}\right\}, \text { where } \hat{R}<\bar{R}
$$

namely, after some simple algebra

$$
\omega^{*}=(\bar{g}-\alpha \bar{\pi}-\bar{R})+\frac{\frac{\eta^{d}}{\eta^{c}}(\alpha+\beta)(\hat{\pi}-\bar{\pi})+(\bar{R}-\hat{R})}{(\alpha+\beta) \lambda \mu \eta^{d} \beta} .
$$

Consequently, we find that $\frac{d \omega^{*}}{d \hat{\pi}}>0$, and moreover that $\frac{d \tilde{R}\left(\omega^{*}\right)}{d \hat{\pi}}=-\lambda \eta^{d}\left[\alpha+\frac{d \omega^{*}}{d \hat{\pi}}\right]<0$ : a stronger inflation target increases deforestation when the transfer is an additional tax or a debt relief, consistent with the results in the main text. 


\section{Appendix A2. Variables' definitions and sources}

\author{
Variables \\ Dependent variable: \\ Deforestation \\ Explanatory variables: \\ Interest variables
}

Seigniorage 1

Seigniorage 2

Control variables

$\log ($ GDPPC $) \quad$ and IntConf

GovStab

TotPop

UrbPop

IntRate

Growth

GovSpend

DebtBurden

Reer

ReerInst

\section{External Instrument}

NbTurnover

Turnover rate of central bank
governors

Average annual deforestation rate, $\%$

Seigniorage: Change in reserve money over GDP. Changes in reserves are in current LCU between $t$ and ( $t$-1) over GDP measured at $t$.

GDP per capita, constant 2000 USD

Internal Conflicts: assess "the political violence in the country and its actual or potential impact on governance". An increase means an improvement i.e. a decrease in violence

Government Stability: assess "both the government's ability to carry out its declared program(s), and its ability to stay in office". An increase means an improvement

Population, total

Urban population, percentage of total

Lending interest rate adjusted for inflation as measured by the GDP deflator

GDP per capita growth, annual \% GDP goods, services and income

Real effective exchange rate, base 100 in 1990. Weights determined by the country's first ten partners (imports and exports), oil countries excluded or not. An increase means a real appreciation. Instability of Reer
Source

FAOSTAT, 1990-2010

WDI

Government consumption, in $\%$ of

Total debt service, in $\%$ of export of

Authors' calculations, as the squared residuals of the country-individual regressions of Reer on one-year lagged Reer and a deterministic trend

Beginning of period. Dreher et al. (2008); Dreher et al. (2010)

Note: unless otherwise stated, all variables are 5-year averages. 


\section{Appendix A3. The list of countries}

Latin American and the

Carribean (20)

Argentina

Belize

Bolivia

Brazil

Chile

Colombia

Costa Rica

Ecuador

El Salvador

Guatemala

Guyana

Honduras

Mexico

Nicaragua

Panama

Paraguay

Peru

Suriname

Uruguay

Venezuela, RB

\section{Sub-Saharan Africa (41)}

Angola

Benin

Botswana

Burkina Faso

Burundi

Cameroon

Central African Republic

Chad

Congo, Dem. Rep.

Congo, Rep.

Cote d'Ivoire

Equatorial Guinea

Eritrea

Ethiopia

Gabon

Gambia, The

Ghana

Guinea

Guinea-Bissau

Kenya

Lesotho

Liberia

Malawi

Mali

Mauritania

Mozambique

Namibia

Niger

Nigeria

Rwanda

Senegal

Sierra Leone

Somalia

South Africa

Sudan

Swaziland

Tanzania

Togo

Uganda

Zambia

Zimbabwe
East Asia and the

Pacific (12)

Brunei Darussalam

Cambodia

China

Korea, Dem. Rep.

Korea, Rep.

Lao PDR

Malaysia

Mongolia

Myanmar

Thailand

Timor-Leste

Vietnam 